\title{
Evolution of the business and management research in Chile
}

\author{
María S. Etchebarne* \\ Department of Business, \\ Faculty of Economics and Business, \\ University of Chile, \\ Santiago, 8330015, Chile \\ Email: setchebarne@unegocios.cl \\ ${ }^{*}$ Corresponding author
}

\section{Christian A. Cancino and José M. Merigó}

Department of Management Control and Information Systems, Faculty of Economics and Business,

University of Chile,

Santiago, 8330015, Chile

Email: cancino@fen.uchile.cl

Email: jmerigo@fen.uchile.cl

\begin{abstract}
Different aspects have enhanced the development of scientific research in business and management in Chile. The aim of this paper is to analyse the characterisation of this scientific evolution. The method used is a Bibliometric analysis. Our sample examines any paper published between 1991 and 2015 in the Web of Science (WoS) database in the area of business and management. The main results show that the publications have had a significant increase. Scientific productivity increase may be related, among other factors: to the efforts of the Chilean universities that reward and incentivise publications in WoS; the participation of academics in competitive grants (Fondecyt); and international accreditations that demand more productive universities in terms of research. The results of the study could be interesting for universities from developing countries wishing to generate policies to increase the productivity in the areas of business and management.
\end{abstract}

Keywords: business and management research; bibliometric analysis; ranking; Chile.

Reference to this paper should be made as follows: Etchebarne, M.S., Cancino, C.A. and Merigó, J.M. (2019) 'Evolution of the business and management research in Chile', Int. J. Technology, Policy and Management, Vol. 19, No. 2, pp.108-130.

Biographical notes: María S. Etchebarne is an Associate Professor in the Department of Administration/Business at the University of Chile. She completed her PhD in Administration at the University of Sevilla, Spain. She has been involved for 20 years in teaching entrepreneurship to university students and entrepreneurs of small firms. Currently, she is dedicated to research and she has given numerous presentations at international conferences, authored journal papers and book chapters. 
Christian A. Cancino is an Associate Professor at the University of Chile and Visiting Professor at San José State University (2018-2019). He works in the design and implementation of corporate performance management systems and the development of several studies and research that use bibliometric analysis method. He has published more than 40 papers in journals, books and conference proceedings. Also, he holds a $\mathrm{PhD}$ in Economics from the Autonomous University of Madrid and a BA in Business Administration and a BA in Management Control Engineering from the University of Chile.

José M. Merigó is a Professor at University of Technology Sydney (Australia) and a Part-Time Professor at the University of Chile. Previously, he was a Senior Research Fellow at the University of Manchester (UK) and an Assistant Professor at the University of Barcelona (Spain). He has published more than 400 papers in journals, books and conference proceedings. He is on the editorial board of several journals including Computers \& Industrial Engineering and Applied Soft Computing. He has participated in many scientific committees.

This paper is a revised and expanded version of a paper entitled 'Promotion of scientific production in business and management research in Chile: a bibliometric analysis' presented at the International Association for Fuzzy-Set Management and Economy (SIGEF 2017), New Rochelle, New York, USA, 7-9 June, 2017.

\section{Introduction}

This paper seeks to demonstrate the development that scientific publications in the areas of business and management have had in the last 25 years in Chile, parallel to the economic and social development that the country has experienced in the same period.

In recent decades, globalisation, the open market and technology have increased trade and business between countries around the world. In Latin America, the Chilean economy was one of the pioneers in joining this process of trade liberalisation in the early 1980s, consolidating in the 1990s. In this regard, the World Bank (2016) states "Chile has been one of Latin America's fastest-growing economies over the past decade". Gross Domestic Product figures reflect the growth experienced by the country in the period, advancing from a GDP per capita of US $\$ 2,388$ in 1990 to US $\$ 21,980$ in 2014 (World Bank, 2016), amounts are deflacted. In this open and competitive scenario, Chilean companies have had to take an active and adaptive role to remain competitive, resolutely managing the opportunities and threats an open economy offers.

Parallel to this economic growth, Business schools in Chile have had to confront the challenge of forming professionals who are able to manage and lead these companies, in a gradually more complex, globalised and competitive market. In response, they have had to make significant efforts to improve the quality of their formation processes, both at undergraduate and postgraduate levels. The above, has also had to be connected with strengthening scientific research of business and management at the discipline level, forming and incorporating researchers who are capable of generating first level knowledge into their classrooms. Different authors state that at the beginning of the nineties, scientific production in the areas of business and management was very incipient in Chile and Latin America, which has evolved positively in recent years 
(Olavarrieta and Villena, 2014; Olavarrieta, 2015; Ronda-Pupo, 2016; Coronado et al., 2016).

On the other hand, the Chilean Government, through the National Commission for science and technology research (Conicyt) has made a major effort to promote the formation of advanced human capital, by creating the Advanced Human Capital (PFCHA) training programme in 1998, which has reached 493 graduates in the international doctorate Conicyt program. In this same program, economy and administration areas have graduated 15 and 9 doctors respectively in prestigious universities in the USA and Europe (Conicyt, 2016). These and dozens of graduates from doctoral programs from the USA and Europe have been incorporated into different Business schools in the country, contributing with new knowledge and practices acquired in their training. Likewise, the arrival of foreign doctors in the business and management field who have been integrated to academic teams of national universities has been substantial. This has generated a critical mass of researchers in the discipline in Chile, who must also comply with scientific productivity requirements as defined by their schools and universities, to maintain quality and competitiveness standards required in the rankings and foreign and national accreditation systems.

Another remarkable fact, in addition to the development of the discipline, is the creation of three doctoral programs in business and management in the country: in 2009 Universidad Adolfo Ibañez, in 2010 Universidad de Santiago de Chile and in 2016 Universidad de Chile. Graduates from these programs are expected to also strengthen the critical mass of researchers that will help generate new knowledge in the discipline, together with directing their contributions and research in the Chilean and Latin American field. Part of the results of this effort, both from public and private universities, to improve quality education standards and levels in business and management, can be observed in the presence of the main Business schools in Chile in the top 10 MBA ranking in Latin America (America Economia, 2016). In addition, in terms of international accreditation, the same three previous Business schools have prestigious international quality certifications such as Association of MBAs (AMBA) and The Association to Advance Collegiate Schools of Business (AACSB) that require the compliance of high standards of international quality, becoming world class Business schools at an international level (AACSB, 2016).

The above has had an effect on productivity growth of scientific papers related with the discipline, which has allowed Administrative Sciences to be in the process of increasing, which has led Chile to be in a prominent place in the Latin American field, in comparison to the 1990s. Hence, in a Bibliometric study conducted by Coronado et al. (2016), regarding the most productive institutions in Latin America in business and management, they conclude that Brazil is in first place, followed by Chile and Mexico respectively.

The business and management discipline has undoubtedly grown and developed in the last 25 years in Chile. However, this increase of value in the scientific productivity of the discipline has not been studied in depth, nor has there been a characterisation. Therefore, this research, through Bibliometric analysis (Broadus, 1987; Cancino et al., 2017a), expects to obtain a characterisation of business schools researchers' scientific publications in Chile present in the WoS in the last 25 years. Among others aspects analysed are: the evolution of the publications in the study period; which discipline areas have published the most, which universities are most prominent in publications, who forms the international university networks with which Chilean university academics 
publish; which scientific journals are publishing and what are their respective impact indexes.

After the present introduction this paper is organised in the following way: in the second section, a brief review of the literature is presented. In the third section, the Bibliometrics methodology used for the analysis is examined. In the fourth section, the results including the evolution of the number of publications and areas of management they are related to, university rankings and research network analysis are presented. The fifth section discusses the main results and conclusions of the paper.

\section{Business and management scientific production in Latin America}

It is worth noting that the business and management discipline has globally presented sustained and rapid growth in the past 25 years, in terms of scientific production, where the effort made by the Academy of Management Society (AoM) has been very relevant (Ronda-Pupo, 2016). In this framework, the main business and management schools in Latin America have not fallen behind. They have had to assume the challenge of delivering quality education, forming capable and competent professionals who are required by companies and organisations which are operating in an increasingly global and competitive market. Therefore, in recent decades, leading business and management schools in Latin America have made significant efforts to improve their quality, both at undergraduate and postgraduate levels, which has also helped to improve their scientific productivity levels (Bonilla et al., 2015).

\subsection{Studies on scientific production in Latin America}

Studies at the Latin American level on the evolution of the administration and management discipline are scarce (Koljatic and Silva, 2001), fragmented and are concentrated in research lines (Nicholls-Nixon et al., 2011). In a recent study performed by Olavarrieta and Villena (2014), they state that in Latin America, business research has increased in the last 5 to 10 years, being in its initial phase. In addition, they state that the impulsors of this development and its future are the challenges business schools have to join international accreditation processes, new doctors who are forming outside Latin America, along with the creation of new prestigious Latin American university doctoral programs.

Ronda-Pupo (2016) in his research assessed the dynamics of the evolution scientific publications on management as a discipline of academic research in Latin America and the Caribbean for the past 25 years. His results show that the areas with the greatest development have been strategic management and innovation and technology management, while the less developed areas are related with entrepreneurship, cooperation and public sector management.

An important aspect to consider is the small number of business and management area journals of Latin American origin indexed in the WoS (former ISI, Institute for Scientific Information) or Scopus and the perceived quality they have. In a survey by Olavarrieta (2015), regarding the perceived quality of Latin American journals, the highest assessments were obtained by Academia (Cladea - Uniandes), RAE (Fundação Getulio Vargas), and Innovar (Universidad Nacional de Colombia). The author states that these data are accompanied by another study by Ruiz-Torres, Penkova and Villafane 
(2012) based on management journals published in Spanish, where the results show that the language and journal's name exert an effect on their perceived quality. Moreover, Romero-Torres et al. (2013) state that the future of scientific journals in Latin America is uncertain, especially due to the inability to calculate useful bibliometric indicators in order to classify them and approve them by quartiles recognised worldwide that reduce their visibility. This situation discourages researchers from submitting their papers to these journals, generating a difficult situation.

On the other hand, university networks and circuits to which researchers are connected apparently have an influence or relationship with publications results. Gantman and Fernández Rodríguez (2016) conducted a study on the academic production of Spanish-speaking countries in the field of management and organisation, differing by the language of the publication, revealing that the researcher's human and social capital affect the segment where he publishes his paper. Likewise, they identified that regardless of personal characteristics, the type of institution to which academics are affiliated appears to influence the segment of journals in which they publish.

\subsection{Promoting scientific production in business schools in Chile}

An important group of Chilean universities are making significant efforts and spending a great number of resources as a way of promoting scientific publications present in the Web of Science TM Core Collection (WoS) by Chilean Business schools academics. Many of these universities, not only want to be leaders in the scientific development in the country, but also to achieve a position in the region that promotes the dissemination of knowledge across borders, being also recognised at an international level.

According to three interviews and two meetings held with board members from business schools in Chile, such as the Universidad de Chile, Pontificie Universidad Católica de Chile, Universidad Adolfo Ibañez and another group of twelve board members participating in the Association of Superior board members of the Faculties of Administration, Business or Entrepreneurs (ASFAE) in Chile, organisation which is integrated by the Deans of Chilean universities offering careers in the areas of management, business or entrepreneurship, it is possible to develop the following list of activities that seek to promote scientific development in the areas of business and management in the country:

- Delivery of monetary funds in support of research (amounts ranging from US\$2,000 to US\$ 6,000 gross depending on University interviewed). The general objective of these funds is to support and foster scientific production of academics in business and management from universities in Chile in their first years of academic development, verifiable through WoS scientific publications and competitive research projects awarded. These funds cannot be used in any type of expenses, but instead are usually restricted to the following concepts:

- hiring research assistants

- academics trips abroad to work with co-authors on publications in WoS papers

- trips to attend international conferences to present academic work 
- expenses associated to the acquisition of goods in direct support to research (books, specialised reports, specialised scientific journals, specialised software, and specialised hardware).

- $\quad$ Support to apply to competitive research projects from the National Fund for scientific and technological development (Fondecyt). Fondecyt aims to stimulate and promote the development of basic scientific and technological research, and is the main Fund of its kind in the country. The purpose of the support that universities give, through mentoring, training and workshops is to encourage academics to apply (at some universities this is an obligation as an annual activity for each academic) to one of the three competitions that Fondecyt has: Regular Projects, from initiation to investigation, and postdoctoral. First, the Regular Projects are oriented to renowned researchers. The project contemplates financing for personnel (researchers, technical staff and thesis candidates), researchers' travel, resources to bring foreign contributors for a short period, operating expenses, equipment and infrastructure support and administration expenses for sponsoring institutions. Second, Initiation Research Projects are aimed at young researchers who have obtained a doctoral degree in the last five years. The project includes the same eligible items as in the regular competition. Third, postdoctoral projects are aimed at young researchers who have obtained a doctoral degree in the past three years. The responsible researcher must count with a sponsoring researcher and a sponsoring institution. The project contemplates fees for the postdoctoral fellow, research support, health insurance and relocation expenses if needed. The monetary contribution of the previous funds ranges between US\$10,000 and US\$15,000 annually, according to the characteristics of each project, which can have a maximum duration of 4 years.

- Monetary Bonus for every WoS 'scientific publication' in accordance with its impact factor, journal quartile or paper influence score. 'Scientific journal' is defined as one published in a journal that is indexed in the Web of Science TM Core Collection (former ISI). Papers such as book reviews, Introductory papers for special editions of journals, and guest editors' introductions are usually excluded from these awards; among other types of publications that have not been accepted through a peer review process, publishers or journal researchers. The amount of the monetary bonus is not always fixed, many times, it depends on the criteria of each University, and on certain rules, in which a performance measure is used, such as

- impact factor of the journal where the academic publishes

- the classification of the journal in Q1, Q2, Q3 or Q4 within the set of each discipline, or

- according to the paper Influence Score.

However, in Chile the impact factor continues being the most used index to evaluate the scientific quality of the journal where an paper is published.

Considering business schools that show monetary bonus outlines for journals in WoS, it was possible to create the following scale of awards according to each journal impact factor: 
- WoS publications with an impact factor greater than or equal to 2: bonus ranging from US\$ 1,000 to US\$ $6,000 *$

- WoS publications with an impact factor greater than or equal to 1.0 and less than 2.0: bonus ranging from US\$ 500 to US\$ 4, 000*

- WoS publications with an impact factor greater than or equal to 0.7 and less than 1.0: bonus ranging from US\$ 400 to US\$ 2, $000 *$

- WoS publications with an impact factor greater than or equal to 0.3 and less than - bonus ranging from US\$ 400 to US\$ $1,000^{*}$

- WoS publications with an impact factor greater than or equal to 0.0 and less that 0.3 : bonus ranging from US\$ 0 to US\$ 600*

*There is a high variance between the universities interviewed regarding awards given to academics who submit publications in WoS. Hence, the previous classification should be revised with caution and does not represent a recommendation for Business Schools.

The set of efforts and previous activities (funding delivery to support scientific research, promoting applications for competitive funds of Fondecyt; or the prizes and bonuses delivery for papers in $\mathrm{WoS}$ ) as a whole, seek to support the scientific production of academics in Chile, and encourage participation and allocation of (national or international) competitive grants in support of research projects. This set of rules and activities has not been a Chilean invention; they have followed the most renowned university practices worldwide, which also feature research programmes and promotion plans among their academics.

Naturally, and after an important number of years since Business Schools in Chile began to promote and to apply these support systems and incentives in research, we can evaluate certain impacts in the results.

The research questions that arise in this scenario and that we hope to respond with this research are: Which has been the evolution, in terms of quantity, of business and management scientific papers published by Chilean researchers in recent years? What will the impact indexes of those publications be? How has the administration area behaved in comparison with the publications of the economy area in the same period? In which journals are the academics of the area publishing? What are the most influential networks used to generate new knowledge in the area? This information allows validating that scientific research in Administration has earned its place in the Latin American and national scenario, and on the other hand, knowing the characterisation of these publications and their main actors.

\section{Methodology}

Currently, it is possible to find a large number of scientific papers that analyse a literature review in business areas (Kaushik et al., 2014; Rehman et al., 2015; Merigó et al., 2016; Cancino et al., 2017b; Cancino et al., 2018). The methodology used in this work is a Bibliometric analysis (Laengle et al., 2017; Valenzuela et al., 2017). Broadus (1987) defines bibliometrics as a quantitative study of bibliographic material. In this work various indicators of scientific production are analysed in the areas of business and management in Chile, which are: the total productivity (total number of publications), the 
influence of the papers (total number of citations) and the influence with regard to productivity ( $h$-index). In recent years Bibliometric analysis has become popular due to the advance of information technologies and the internet that have allowed using and analysing complete databases and information on scientific publications at a global level (Merigó et al., 2015).

The database used for the analysis was obtained from Web of Science TM Core Collection (WoS), selecting the last 25 years of publications (1991-2015).

In order to obtain Bibliometric information about business and management in Chile, the research area 'business economics' was chosen, in addition to WoS categories of 'management', 'business', 'business finance' and 'public administration'. Subsequently, the data was filtered by type of document 'paper', to finally choose 'Chile' as the country of analysis. 1,313 results were obtained up to July, 2016.

After the results are obtained, they are ordered and analysed in classifications by universities and journals, depending on the following key variables:

- $\quad$ TPX: total publications on X research area. X can be $\mathrm{M}$ (general management or as a sub-area of management), B (business), BF (business finance) and PA (public administration).

- $\quad$ TCX: total citations on X research area. X can be M (general management or a sub-area of management), B (business), BF (business finance) and PA (public administration).

- HX: H index on X research area. X can be M (general management or a sub-area of management), B (business), BF (business finance) and PA (public administration). The $\mathrm{H}$ index measures the influence of the classification analysed, for example: If University ' $A$ ' has a value $H$ ' $y$ ' means that ' $y$ ' of their publications received at least ' $y$ ' citations. This variable is used to generate the rankings that are displayed in the results section.

- TCX/TPX: proportion of citations on publications about X research area. X can be $\mathrm{M}$ (general management or a sub-area of management), B (business), BF (business finance) and PA (public administration).

- $\mathrm{P} \%$ : percentage of participation of publications in management/sub-area of Chile management over total global publications

- $\quad$ TPG: total global publications of the analysed item (University or journal), unfiltered by research area.

In order to map graphically the bibliographic results, the study uses the VOS viewer software (Van Eck and Waltman, 2010). With the software, the work develops bibliographic coupling (Kessler, 1963) of universities and journals (Blanco-Mesa et al., 2017). Recall that bibliographic coupling occurs when two documents cite the same third work (Cancino et al., 2017c; Tur-Porcar et al., 2018).

As previously mentioned, the results are classified by universities (Chilean and foreign collaborating ones) and by journals where the research is published. The rankings are constructed in accordance with the $h$-index. In the following section the major findings of the Bibliometric analysis of the data are presented. 


\section{Main results}

This section presents the major findings of the paper. First, the section develops a growth series of the business and management discipline and its subareas of analysis (management, business, business finance and public administration). Second, the study developed a ranking of the leading universities in business and management research in Chile. Third, the paper analyses the journals present in WoS where academics in business and management in Chile publish the most. Fourth, an analysis of the journals which academics from Chilean universities most publish on management, business, business finance and public administration is presented. Finally, the study presents the most influential foreign universities to collaborate in research with Chilean universities.

\subsection{Research area growth in business and management in Chile}

The main results obtained from the analysis of scientific papers in WoS by academics from Chilean universities in the mentioned period, show that a sharp increase occurs from the year 2000 onwards in the business and management area (see Figure 1). The relevance of this increase can be measured if we analyse the business and management publications, produced in the last five years (2011-2015) that reached the figure of 376, compared with 293 papers that were published in total between 1991 and 2010.

In Figure 1 it is possible to observe that at the beginning of the 1990s very little was published in the areas of business and management in Chile, which could be very different to the number of publications in other scientific areas, such as in economy or in engineering, which already showed a growth in the number of scientific publications in those years. But, how has the growth in the number of scientific publications been within the subareas of business and management (management, business, business finance and public administration). Figure 2 shows that in the last 10 years specialisation has occurred in the sub-areas of management, where the most exploited are management and business. The area of business finance presents an increase from 2007 onwards and then it stabilises, while the area of Administration public presents a decrease in those last years.

Figure 1 Total publications in business and management research in Chile (see online version for colours)

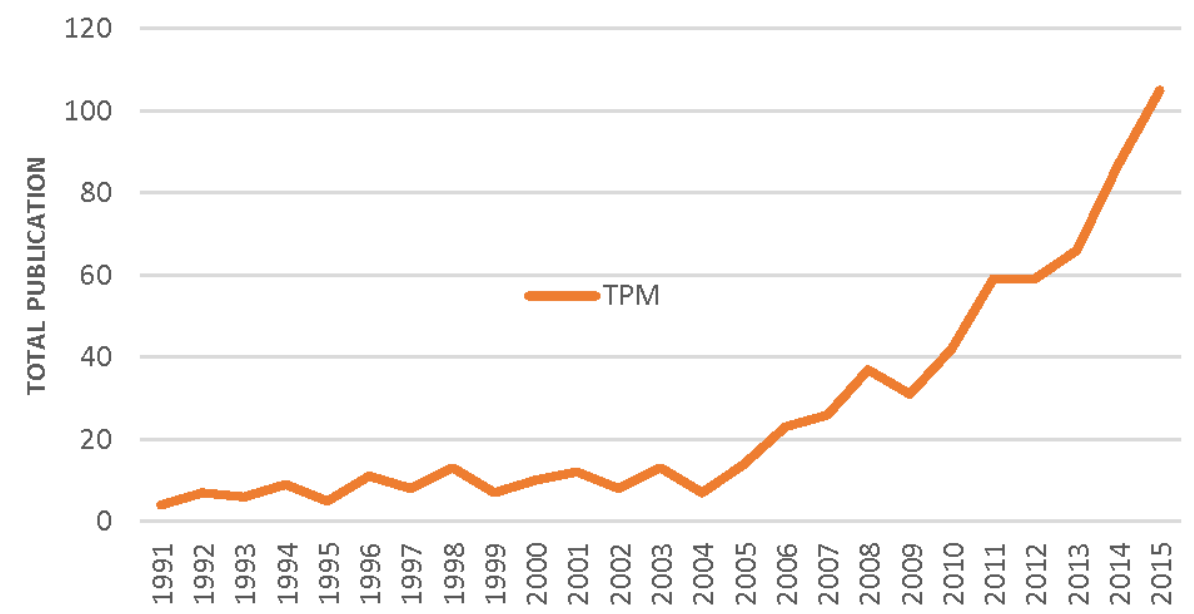


Figure 2 Growth by sub-area of management in Chile (see online version for colours)

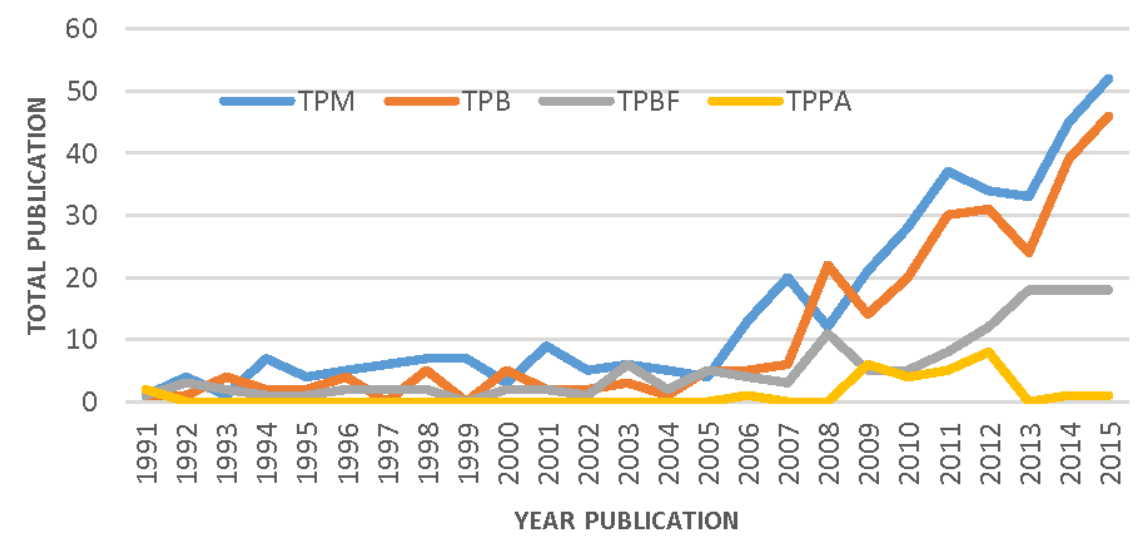

TPM: Total publication in Management; TPB: Total publication in Business; TPBF: Total publication in Business Finance; TPPA: Total publication in Public Administration.

When we observe the subareas of business and management it is possible to notice that the increase in major publications in WoS has been produced in the last 10 years. According to what is mentioned by the directors of ASFAE, it is precisely in these last 10 years when it has been observed that Chilean universities are making a greater effort to increase the number of their scientific publications, which is evidenced in the following aspects:

- Since 2005, Chilean universities particularly Business Schools have begun to increase the number of academics with a $\mathrm{PhD}$ or Doctoral degree who are recruited. Business schools are beginning to differentiate those academics with doctorates, from those who only have a master's degree. The first are asked to take fewer courses per year, in relation to their peers who only have a master's degree, in order to focus their efforts on research, a condition that is maintained only while they show scientific publications.

- Scientific production incentive schemes begin to be applied and Business School academics are encouraged to apply to Fondecyt programs.

\subsection{The most influential Chilean universities in business and management research}

In Table 1 it is possible to see the ranking of the most productive and influential Chilean universities in business and management research. In this ranking not only do the numbers of scientific publications in the WoS for the period 1991 to 2015 appear, but also the number of citations of the set of these publications. Universities are ranked by their $h$-index.

In accordance with the results in Table 1 the Chilean universities with the highest $h$-index, and that are also those which publish most in themes related with business and management, are Universidad de Chile, Pontificia Universidad Católica de Chile and Universidad Adolfo Ibáñez. These three universities gather more than $68 \%$ of the publications in business and management in Chile. With regard to citations, these three universities have more than $82 \%$ of the citations on academic items present in WoS. 
Clearly, the three universities mentioned are leaders in Chile in high impact scientific production in business and management research.

It is important to highlight Universidad Adolfo Ibanez's case, which presents $17.8 \%$, a very high percentage of publications in business and management based on the total number of publications by the University, which demonsrates how specialised this University is in business and management, in relation to the work the other two universities show (Universidad de Chile and Pontificia Universidad Católica de Chile), where their academics publish more in other scientific areas.

After establishing the Group of universities with the highest $h$-index in business and management research, it is possible to identify an important number of Chilean universities that are making efforts to publish in WoS. The following are prominent in these cases: Universidad de Talca, Universidad de Los Andes, Universidad del Desarrollo, Universidad Diego Portales, Universidad de Concepción, Universidad Alberto Hurtado, Universidad de Santiago de Chile, Universidad del Bio Bio, Universidad Católica del Norte, Universidad Técnica Federico Santa María, and the Pontificia Universidad Católica de Valparaíso. The rest of the universities, half of the ranking, are making very little effort to increase scientific production by their academics.

When different board members from the top 10 universities of the previous ranking were asked about the existence of incentive systems that motivate scientific publishing, all stated that the University provided funding to support scientific research, or it encouraged its academics to apply to competitive funds of Fondecyt, and in most cases, that there were monetary awards and bonuses for papers published in WoS. In the case of the first three universities in the ranking, all the above options are given together.

Figure 3 presents a bibliographic coupling analysis among Chilean universities for the period 1991-2015 with a threshold of five documents and 50 connections. Recall that bibliographic coupling between universities occur when the documents of two universities cite frequently the same third documents (Martínez-López et al., 2018; Merigó et al., 2018). As we can see Universidad de Chile, la Pontificie Universidad Católica de Chile and Universidad Adolfo Ibañez are the main network centres that show what academics in Chile are studying. Note that the connections show the universities that tend to cite the same bibliographic material, i.e., that analyse material in common.

Table 1 Ranking of Chilean universities in management research

\begin{tabular}{llcccccc}
\hline$R$ & University & $T P M$ & $T C M$ & $H M$ & $T C M / T P M$ & $\% P$ & $T P G$ \\
\hline 1 & Universidad de Chile & 231 & 2,070 & 27 & 8.96 & $1.0 \%$ & 23,829 \\
2 & Pontificia Universidad Católica de & 157 & 1,586 & 23 & 10.10 & $0.9 \%$ & 17,302 \\
& Chile & & & & & & \\
3 & Universidad Adolfo Ibáñez & 105 & 998 & 13 & 9.50 & $17.8 \%$ & 590 \\
4 & Universidad de Talca & 27 & 137 & 7 & 5.07 & $1.6 \%$ & 1,737 \\
5 & Universidad de Los Andes & 19 & 103 & 6 & 5.42 & $2.7 \%$ & 695 \\
6 & Universidad del Desarrollo & 23 & 106 & 5 & 4.61 & $3.4 \%$ & 676 \\
\hline
\end{tabular}


Table 1 Ranking of Chilean universities in management research (continued)

\begin{tabular}{|c|c|c|c|c|c|c|c|}
\hline$R$ & University & $T P M$ & $T C M$ & $H M$ & $T C M / T P M$ & $\% P$ & $T P G$ \\
\hline 7 & Universidad Diego Portales & 25 & 96 & 5 & 3.84 & $2.1 \%$ & 1,168 \\
\hline 8 & Universidad de Concepción & 16 & 95 & 5 & 5.94 & $0.2 \%$ & 9,430 \\
\hline 9 & Universidad Alberto Hurtado & 7 & 40 & 5 & 5.71 & $3.1 \%$ & 224 \\
\hline 10 & Universidad de Santiago de Chile & 27 & 71 & 4 & 2.63 & $0.6 \%$ & 4,645 \\
\hline 11 & Universidad del Bio Bio & 9 & 66 & 4 & 7.33 & $0.9 \%$ & 1,012 \\
\hline 12 & Universidad Católica del Norte & 16 & 58 & 4 & 3.63 & $0.6 \%$ & 2,574 \\
\hline 13 & $\begin{array}{l}\text { Universidad Técnica Federico Santa } \\
\text { María }\end{array}$ & 8 & 49 & 4 & 6.13 & $0.3 \%$ & 3,069 \\
\hline 14 & Universidad Austral de Chile & 4 & 42 & 3 & 10.50 & $0.1 \%$ & 4,538 \\
\hline 15 & $\begin{array}{l}\text { Pontificia Universidad Católica de } \\
\text { Valparaíso }\end{array}$ & 7 & 25 & 3 & 3.57 & $0.2 \%$ & 2,866 \\
\hline 16 & Universidad Santo Tomás & 3 & 18 & 3 & 6.00 & $1.0 \%$ & 289 \\
\hline 17 & $\begin{array}{l}\text { Universidad Católica de la Santísima } \\
\text { Concepción }\end{array}$ & 6 & 30 & 2 & 5.00 & $1.2 \%$ & 492 \\
\hline 18 & Universidad de Tarapacá & 5 & 27 & 2 & 5.40 & $0.4 \%$ & 1,170 \\
\hline 19 & Universidad de Valparaíso & 3 & 5 & 2 & 1.67 & $0.1 \%$ & 2,030 \\
\hline 20 & $\begin{array}{l}\text { Universidad Católica Silva } \\
\text { Henríquez }\end{array}$ & 1 & 9 & 1 & 9.00 & $2.6 \%$ & 39 \\
\hline 21 & Universidad Gabriela Mistral & 1 & 8 & 1 & 8.00 & $10.0 \%$ & 10 \\
\hline 22 & Universidad Católica del Maule & 1 & 7 & 1 & 7.00 & $0.3 \%$ & 289 \\
\hline 23 & Universidad Andrés Bello & 2 & 3 & 1 & 1.50 & $0.1 \%$ & 2,234 \\
\hline 24 & Universidad Autónoma de Chile & 5 & 2 & 1 & 0.40 & $0.9 \%$ & 588 \\
\hline 25 & Universidad de La Serena & 2 & 2 & 1 & 1.00 & $0.2 \%$ & 885 \\
\hline 26 & Universidad Finis Terrae & 3 & 1 & 1 & 0.33 & $2.8 \%$ & 106 \\
\hline 27 & Universidad San Sebastián & 1 & 1 & 1 & 1.00 & $0.4 \%$ & 238 \\
\hline 28 & Universidad de La Frontera & 3 & 0 & 0 & 0.00 & $0.1 \%$ & 2,519 \\
\hline 29 & Universidad de Los Lagos & 2 & 0 & 0 & 0.00 & $0.4 \%$ & 562 \\
\hline 30 & Universidad Arturo Prat & 1 & 0 & 0 & 0.00 & $0.3 \%$ & 393 \\
\hline 31 & Universidad de Las Américas & 1 & 0 & 0 & 0.00 & $5.3 \%$ & 19 \\
\hline
\end{tabular}

Abbreviations: $\mathrm{R}=$ Rank; TPM $=$ Total number of publications in management research; $\mathrm{TCM}=$ Total number of cites in management research; $\mathrm{HM}=h$-index in management research; $\mathrm{TCM} / \mathrm{TPM}=$ Total number of cites in management research over Total number of publications in management research; TPG $=$ Total number of publications in any discipline; $\% \mathrm{P}=\mathrm{TPM}$ over TPG.

\subsection{Journals where Chilean universities most publish about business and management}

Not only is it important to know if the academics of the Chilean universities are publishing more in business and management, but also it is interesting to know in which journals they are publishing. For Chilean academics, and in the region, it could be useful 
to know which journals pay more attention to local issues, i.e., where local issues occurring in Chilean companies are studied and where the potential results could possibly be exported to other developing countries. Hence, they would likely accept these papers for publication and subsequent dissemination in the region or around the world.

According to Table 2, Chilean university academics are mainly publishing their research in international journals from the USA and Europe, which have a higher $h$-index, such as European Journal of Operational Research (Europe), Operations Research (USA), Journal of Business Research (USA) and Journal of the Operational Research Society (Europe). However, there is a Latin American journal, which although it does not have a high $h$-index value, and therefore has no better position in the ranking, it presents a great number of publications by Chilean academics.

Consulting university board members on why they think that little is published in other Latin-American journals (with the exception of Academia Revista Latinoamericana de Administración that would be in the 35th position of the ranking but with 41 documents published) of WoS, present in the ranking in Table 2, such as INNOVAR Administrative and social sciences journal, RAE Revista de Administracao de Empresas or Revista Venezolana de Gerencia, they expressed the following reasons:

Figure 3 Bibliographic coupling analysis - universities (see online version for colours)

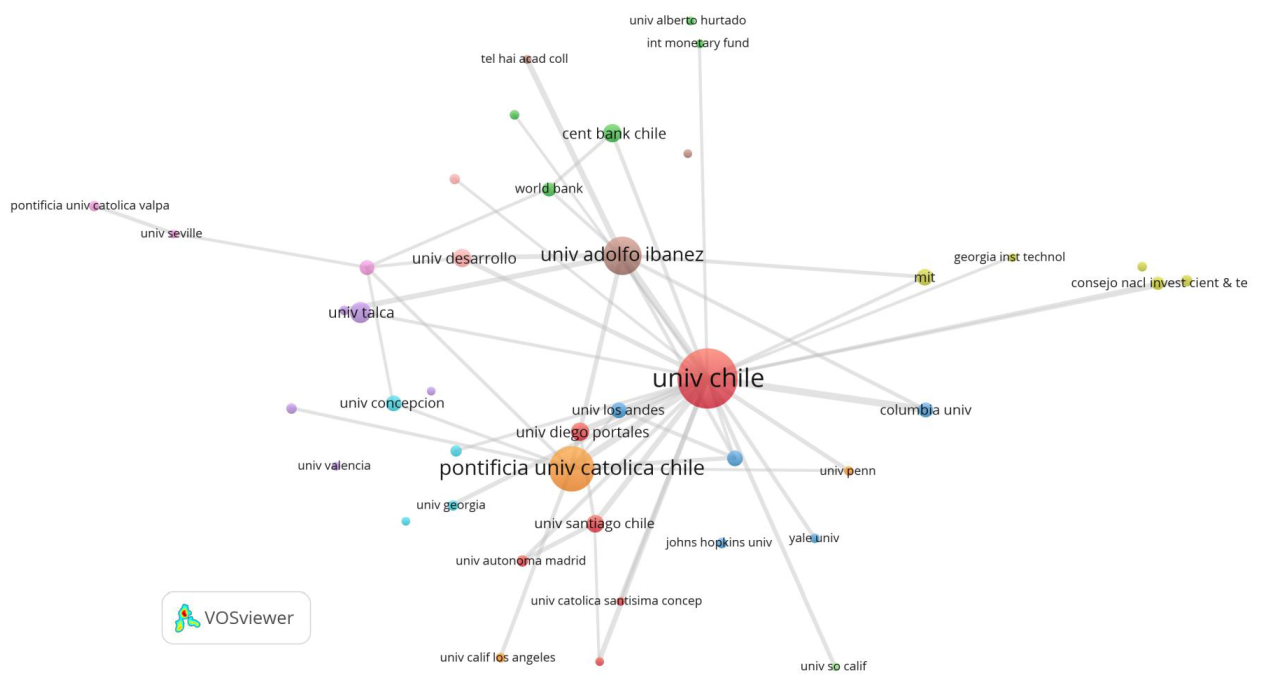

First, in the case of INNOVAR Revista de Ciencias Administrativas y Sociales, ranked 40th, the board members believe that since this journal was excluded from the JCR of WoS in 2012, Chilean academics are not encouraged to publish in it.

Second, in the case of RAE Revista de Administracao de Empresas, being a journal that publishes many papers in Portuguese, this generates a natural barrier for Chilean academics. According to the board members, academics do not always want to submit papers to this journal given the language barrier, which could cause the theme under study to be read by fewer academics from Brazilian universities and this would lead to a smaller number of citations from each publication. 
Table 2 Ranking of journals with more publications of Chilean universities in management research

\begin{tabular}{|c|c|c|c|c|c|c|c|}
\hline$R$ & Journal & $T P M$ & $T C M$ & $H M$ & $T C M / T P M$ & $\% P$ & $T P G$ \\
\hline 1 & European Journal of Operational Research & 57 & 644 & 15 & 11.30 & $0.5 \%$ & 11,568 \\
\hline 2 & Operations Research & 20 & 519 & 12 & 25.95 & $0.9 \%$ & 2,253 \\
\hline 3 & Journal of Business Research & 46 & 318 & 9 & 6.91 & $1.3 \%$ & 3,455 \\
\hline 4 & Journal of the Operational Research Society & 26 & 182 & 9 & 7.00 & $0.7 \%$ & 3,508 \\
\hline 5 & Management Science & 13 & 377 & 7 & 29.00 & $0.4 \%$ & 3,245 \\
\hline 6 & Interfaces & 19 & 218 & 6 & 11.47 & $1.6 \%$ & 1,168 \\
\hline 7 & $\begin{array}{l}\text { Journal of Environmental Economics and } \\
\text { Management }\end{array}$ & 6 & 192 & 6 & 32.00 & $0.5 \%$ & 1,178 \\
\hline 8 & World Bank Economic Review & 10 & 95 & 6 & 9.50 & $1.7 \%$ & 602 \\
\hline 9 & Journal of International Money and Finance & 11 & 72 & 6 & 6.55 & $0.7 \%$ & 1,647 \\
\hline 10 & Journal of Productivity Analysis & 6 & 90 & 5 & 15.00 & $0.8 \%$ & 730 \\
\hline 11 & Group Decision and Negotiation & 7 & 66 & 5 & 9.43 & $1.0 \%$ & 672 \\
\hline 12 & Emerging Markets Finance and Trade & 25 & 59 & 5 & 2.36 & $3.0 \%$ & 823 \\
\hline 13 & Journal of Financial Economics & 5 & 658 & 4 & 131.60 & $0.3 \%$ & 1,861 \\
\hline 14 & Journal of Finance & 4 & 176 & 4 & 44.00 & $0.2 \%$ & 1,857 \\
\hline 15 & Small Business Economics & 8 & 86 & 4 & 10.75 & $0.6 \%$ & 1,320 \\
\hline 16 & Journal of Banking \& Finance & 8 & 76 & 4 & 9.50 & $0.2 \%$ & 3,775 \\
\hline 17 & Research Policy & 4 & 70 & 4 & 17.50 & $0.2 \%$ & 2,097 \\
\hline 18 & Journal of Business Ethics & 8 & 45 & 4 & 5.63 & $0.2 \%$ & 5,294 \\
\hline 19 & Review of Industrial Organisation & 4 & 45 & 4 & 11.25 & $0.5 \%$ & 864 \\
\hline 20 & Journal of Forecasting & 8 & 43 & 4 & 5.38 & $0.9 \%$ & 937 \\
\hline 21 & Journal of Industrial Economics & 6 & 37 & 4 & 6.17 & $0.9 \%$ & 681 \\
\hline 22 & Journal of Monetary Economics & 4 & 777 & 3 & 194.25 & $0.3 \%$ & 1,547 \\
\hline 23 & Family Business Review & 3 & 59 & 3 & 19.67 & $1.5 \%$ & 206 \\
\hline 24 & Journal of Futures Markets & 5 & 53 & 3 & 10.60 & $0.4 \%$ & 1,249 \\
\hline 25 & Journal of Consumer Research & 3 & 53 & 3 & 17.67 & $0.2 \%$ & 1,315 \\
\hline 26 & $\begin{array}{l}\text { Journal of Economics \& Management } \\
\text { Strategy }\end{array}$ & 5 & 50 & 3 & 10.00 & $0.7 \%$ & 711 \\
\hline 27 & Systems Research and Behavioural Science & 5 & 45 & 3 & 9.00 & $0.6 \%$ & 828 \\
\hline 28 & Industrial Marketing Management & 4 & 42 & 3 & 10.50 & $0.2 \%$ & 1,878 \\
\hline 29 & $\begin{array}{l}\text { International Journal of Finance \& } \\
\text { Economics }\end{array}$ & 3 & 35 & 3 & 11.67 & $0.7 \%$ & 455 \\
\hline 30 & $\begin{array}{l}\text { International Review of Economics \& } \\
\text { Finance }\end{array}$ & 5 & 34 & 3 & 6.80 & $0.7 \%$ & 691 \\
\hline
\end{tabular}

Abbreviations: $\mathrm{R}=$ Rank; $\mathrm{TPM}=$ Total number of publications in management research; $\mathrm{TCM}=$ Total number of cites in management research; $\mathrm{HM}=h$-index in management research; $\mathrm{TCM} / \mathrm{TPM}=$ Total number of cites in management research over Total number of publications in management research; $\mathrm{TPG}=$ Total number of publications in any dicipliny; $\% \mathrm{P}=\mathrm{TPM}$ over TPG. 
Third, the Venezuelan journal of management/Revista Venezolana de Gerencia presents very few publications by Chilean academics, only five in the last 25 years. According to the Chilean university boards interviewed, this is a less known journal in Chile; hence the academics have not attempted to publish their research there.

Undoubtedly, Academia Revista Latinoamericana de Administración is challenging other international journals such as European Journal of Operational Research, Operations Research, Journal of Business Research and Journal of the Operational Research Society as outlets for Chilean academic publications in the areas of business and management.

Therefore, it is interesting to analyse Figure 4 where bibliographic coupling analysis is observed for the set of journals in the ranking with a minimum threshold of five documents and 50 connections. Recall that here bibliographic coupling of journals visualise the journals that cite the same third documents. The size of the circles indicates the number of papers published which is in accordance with Table 2.

Figure 4 Bibliographic coupling analysis - journals (see online version for colours)

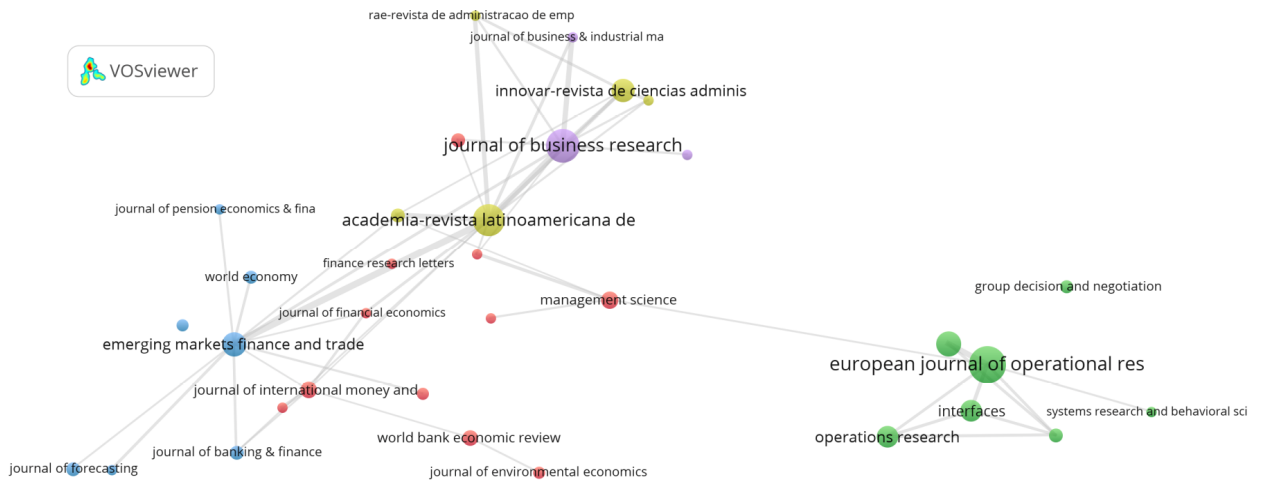

As we can see in Figure 4, European Journal Operational Research, Journal of Business Research and Academia Revista Latino Americana de Administración are the main network centres that tend to cite the same bibliographic material. This shows the connections, in particular the European Journal of Operational Research Centre which is the centre of citations for operations management issues. The Journal of Business Research is the Centre for more general themes that involve marketing, ethics and business in general. The case of Academia Revista Latinoamericana de Administración is similar to the previous one, even though they are interested in frequently citing finance themes.

The three previously mentioned journals are important in the region because they concentrate citations by the greatest number of academics from Chilean universities, defining in some measure, the areas of study in each discipline.

Finally, when we consulted the board members of the three more productive Chilean universities regarding the publication trend of the academics in the business and management areas, they mentioned that nowadays universities are making efforts not only to publish papers in WoS, but also ideally in journals with high international reputation. Therefore, incentive systems that show the Chilean universities that publish the most in the WoS (Universidad de Chile, Pontificia Universidad Católica de Chile and 
Universidad Adolfo Ibáñez) award prizes to publications according to the impact factor of the journal where the paper is published. In the event that the impact factor is very low, although there is no award for research, it is valued as a scientific publication.

\subsection{The most influential Chilean universities by management sub-area}

Tables 3-6 present the most influential universities separated by subarea analysis (management, business, finance and public administration).

Table 3 Ranking of Chilean universities in sub-area of management

\begin{tabular}{|c|c|c|c|c|c|c|c|}
\hline \multicolumn{8}{|c|}{ Management } \\
\hline$R$ & University & $T P M$ & $T C M$ & $H M$ & $T C M / T P M$ & $\% P$ & $T P G$ \\
\hline 1 & Universidad de Chile & 137 & 1,340 & 24 & 9.78 & $0.6 \%$ & 23,829 \\
\hline 2 & $\begin{array}{l}\text { Pontificia Universidad Católica de } \\
\text { Chile }\end{array}$ & 89 & 807 & 15 & 9.07 & $0.5 \%$ & 17,302 \\
\hline 3 & Universidad Adolfo Ibañez & 50 & 700 & 10 & 14.00 & $8.5 \%$ & 590 \\
\hline 4 & Universidad de Talca & 16 & 64 & 5 & 4.00 & $0.9 \%$ & 1,737 \\
\hline 5 & Universidad de Los Andes & 10 & 45 & 5 & 4.50 & $1.4 \%$ & 695 \\
\hline 6 & Universidad del Desarrollo & 15 & 82 & 4 & 5.47 & $2.2 \%$ & 676 \\
\hline 7 & Universidad de Concepción & 11 & 67 & 4 & 6.09 & $0.1 \%$ & 9,430 \\
\hline 8 & Universidad de Santiago de Chile & 19 & 64 & 4 & 3.37 & $0.4 \%$ & 4,645 \\
\hline 9 & Universidad Diego Portales & 11 & 43 & 3 & 3.91 & $0.9 \%$ & 1,168 \\
\hline 10 & $\begin{array}{l}\text { Universidad Católica de La } \\
\text { Santisima Concepción }\end{array}$ & 4 & 28 & 2 & 7.00 & $0.8 \%$ & 492 \\
\hline 11 & $\begin{array}{l}\text { Universidad Técnica Federico } \\
\text { Santa María }\end{array}$ & 3 & 26 & 2 & 8.67 & $0.1 \%$ & 3,069 \\
\hline 12 & $\begin{array}{l}\text { Pontificia Universidad Católica de } \\
\text { Valparaíso }\end{array}$ & 7 & 25 & 2 & 3.57 & $0.2 \%$ & 2,866 \\
\hline 13 & Universidad de Tarapacá & 4 & 24 & 2 & 6.00 & $0.3 \%$ & 1,170 \\
\hline 14 & Universidad Alberto Hurtado & 2 & 8 & 2 & 4.00 & $0.9 \%$ & 224 \\
\hline 15 & Universidad de Valparaíso & 3 & 5 & 2 & 1.67 & $0.1 \%$ & 2,030 \\
\hline 16 & Universidad del Bio Bio & 5 & 14 & 1 & 2.80 & $0.5 \%$ & 1,012 \\
\hline 17 & Universidad Austral de Chile & 1 & 14 & 1 & 14.00 & $0.0 \%$ & 4,538 \\
\hline 18 & $\begin{array}{l}\text { Universidad Católica Silva } \\
\text { Henríquez }\end{array}$ & 1 & 9 & 1 & 9.00 & $2.6 \%$ & 39 \\
\hline 19 & Universidad Católica del Maule & 1 & 7 & 1 & 7.00 & $0.3 \%$ & 289 \\
\hline 20 & Universidad Católica del Norte & 8 & 4 & 1 & 0.50 & $0.3 \%$ & 2,574 \\
\hline
\end{tabular}

It is possible to see that the three universities that most publish in business and management in general, also appear first in each ranking when a subarea analysis is performed. Universidad de Chile, Pontificia Universidad Católica de Chile and Universidad Adolfo Ibañez appear first in the rankings. The exception is in the area of business finance, where Universidad Alberto Hurtado replaces Universidad Adolfo 
Ibáñez, obtaining third place in this subarea. The latter is not connected to the fact that Universidad Alberto Hurtado University is publishing more or is being most often cited; instead it is related to how the $h$-index is built, the method with which we ranked in this study.

It is worth noting the low number of Chilean universities publishing business, finance and public administration topics. Undoubtedly, the effort here is undertaken by the same three large universities that appear first in the rankings.

Table 4 Ranking of Chilean universities in sub-area of business

\begin{tabular}{|c|c|c|c|c|c|c|c|}
\hline \multicolumn{8}{|c|}{ Business } \\
\hline$R$ & University & $T P B$ & $T C B$ & $H B$ & $T C B / T P B$ & $\% P$ & $T P G$ \\
\hline 1 & $\begin{array}{l}\text { Pontificia Universidad Católica } \\
\text { de Chile }\end{array}$ & 52 & 540 & 13 & 10.38 & $0.3 \%$ & 17,302 \\
\hline 2 & Universidad de Chile & 82 & 516 & 12 & 6.29 & $0.3 \%$ & 23,829 \\
\hline 3 & Universidad Adolfo Ibáñez & 62 & 579 & 11 & 9.34 & $10.5 \%$ & 590 \\
\hline 4 & Universidad del Desarrollo & 19 & 98 & 5 & 5.16 & $2.8 \%$ & 676 \\
\hline 5 & Universidad de Talca & 10 & 70 & 3 & 7.00 & $0.6 \%$ & 1,737 \\
\hline 6 & Universidad Diego Portales & 15 & 53 & 3 & 3.53 & $1.3 \%$ & 1,168 \\
\hline 7 & Universidad del Bio Bio & 7 & 53 & 3 & 7.57 & $0.7 \%$ & 1,012 \\
\hline 8 & $\begin{array}{l}\text { Universidad Técnica Federico } \\
\text { Santa María }\end{array}$ & 5 & 39 & 3 & 7.80 & $0.2 \%$ & 3,069 \\
\hline 9 & Universidad Austral de Chile & 2 & 35 & 2 & 17.50 & $0.0 \%$ & 4,538 \\
\hline 10 & Universidad Católica del Norte & 12 & 29 & 2 & 2.42 & $0.5 \%$ & 2,574 \\
\hline 11 & Universidad de Concepción & 7 & 28 & 2 & 4.00 & $0.1 \%$ & 9,430 \\
\hline 12 & $\begin{array}{l}\text { Universidad de Santiago de } \\
\text { Chile }\end{array}$ & 13 & 8 & 2 & 0.62 & $0.3 \%$ & 4,645 \\
\hline 13 & Universidad de Los Andes & 4 & 46 & 1 & 11.50 & $0.6 \%$ & 695 \\
\hline 14 & Universidad Gabriela Mistral & 1 & 8 & 1 & 8.00 & $10.0 \%$ & 10 \\
\hline 15 & Universidad Santo Tomás & 1 & 8 & 1 & 8.00 & $0.3 \%$ & 289 \\
\hline 16 & Universidad de Tarapacá & 3 & 4 & 1 & 1.33 & $0.3 \%$ & 1,170 \\
\hline 17 & $\begin{array}{l}\text { Universidad Católica de La } \\
\text { Santísima Concepción }\end{array}$ & 4 & 2 & 1 & 0.50 & $0.8 \%$ & 492 \\
\hline 18 & Universidad de La Serena & 2 & 2 & 1 & 1.00 & $0.2 \%$ & 885 \\
\hline 19 & Universidad Finis Terrae & 3 & 1 & 1 & 0.33 & $2.8 \%$ & 106 \\
\hline 20 & $\begin{array}{l}\text { Pontificia Universidad Católica } \\
\text { de Valparaíso }\end{array}$ & 1 & 1 & 1 & 1.00 & $0.0 \%$ & 2,866 \\
\hline
\end{tabular}

\subsection{The most influential foreign universities who collaborate with Chilean universities}

Finally, it is interesting to analyse which are the most influential universities to collaborate with researchers from Chilean universities by publishing WoS papers in business and management research. 
Table 5 Ranking of Chilean universities in sub-area of business finance

\begin{tabular}{|c|c|c|c|c|c|c|c|}
\hline \multicolumn{8}{|c|}{ Business finance } \\
\hline$R$ & University & $T P B F$ & $T C B F$ & $H B F$ & $T C B F / T P B F$ & $\% P$ & $T P G$ \\
\hline 1 & $\begin{array}{l}\text { Pontificia Universidad Católica } \\
\text { de Chile }\end{array}$ & 34 & 402 & 10 & 11.82 & $0.2 \%$ & 17,302 \\
\hline 2 & Universidad de Chile & 47 & 269 & 8 & 5.72 & $0.2 \%$ & 23,829 \\
\hline 3 & Universidad Alberto Hurtado & 4 & 33 & 4 & 8.25 & $1.8 \%$ & 224 \\
\hline 4 & Universidad Adolfo Ibañez & 14 & 47 & 3 & 3.36 & $2.4 \%$ & 590 \\
\hline 5 & Universidad Católica del Norte & 3 & 29 & 2 & 9.67 & $0.1 \%$ & 2,574 \\
\hline 6 & Universidad de Los Andes & 2 & 12 & 1 & 6.00 & $0.3 \%$ & 695 \\
\hline 7 & Universidad Austral de Chile & 1 & 7 & 1 & 7.00 & $0.0 \%$ & 4,538 \\
\hline 8 & Universidad Santo Tomás & 1 & 7 & 1 & 7.00 & $0.3 \%$ & 289 \\
\hline 9 & Universidad de Talca & 5 & 3 & 1 & 0.60 & $0.3 \%$ & 1,737 \\
\hline 10 & Universidad Diego Portales & 3 & 3 & 1 & 1.00 & $0.3 \%$ & 1,168 \\
\hline
\end{tabular}

Table 6 Ranking of Chilean universities in sub-area of public administration

\begin{tabular}{llcccccc}
\hline \multicolumn{7}{c}{ Public administration } \\
\hline$R$ & University & $T P P A$ & $T C P A$ & $H P A$ & $T C P A / T P P A$ & $\% P$ & $T P G$ \\
\hline 1 & Pontificia Universidad Católica de & 5 & 8 & 2 & 1.60 & $0.0 \%$ & 17,302 \\
& Chile & & & & & & \\
2 & Universidad Adolfo Ibañez & 1 & 23 & 1 & 23.00 & $0.2 \%$ & 590 \\
3 & Universidad de Chile & 10 & 4 & 1 & 0.40 & $0.0 \%$ & 23,829 \\
4 & Universidad Católica del Norte & 4 & 3 & 1 & 0.75 & $0.2 \%$ & 2,574 \\
5 & Universidad Diego Portales & 1 & 2 & 1 & 2.00 & $0.1 \%$ & 1,168 \\
6 & Universidad de Tarapacá & 2 & 1 & 1 & 0.50 & $0.2 \%$ & 1,170 \\
7 & Universidad de Talca & 3 & 0 & 0 & 0.00 & $0.2 \%$ & 1,737 \\
8 & Universidad de Concepción & 2 & 0 & 0 & 0.00 & $0.0 \%$ & 9,430 \\
9 & Universidad del Bio Bio & 2 & 0 & 0 & 0.00 & $0.2 \%$ & 1,012 \\
10 & Universidad Arturo Prat & 1 & 0 & 0 & 0.00 & $0.3 \%$ & 393 \\
\hline
\end{tabular}

Table 7 shows that Chilean universities mainly collaborate with US universities. In fact, within the first ten universities collaborating in the ranking, $90 \%$ are US universities. In terms of number of publications Chilean academics have 137 publications with US universities, the greatest number between those countries, representing almost $50 \%$ of the publications with the total network of foreign universities. The main universities that publish together with Chilean university academics are MIT, Harvard University and Columbia University.

When collaborating with European universities, two British universities are prominent in the ranking (University of Manchester and University of London) and a University in Portugal (Universidade de Lisboa). The three previous universities present the largest $h$-index values for joint publications of academics from Chilean universities with European universities. Complementing the analysis above, and if we only consider 
the number of publications present in the WoS with European universities, the Spanish universities are with whom Chilean university academics publish the most. After US universities, with which 137 joint publications can be counted, the case of Spanish universities, with which there are 63 joint publications, is relevant. The papers published with Pompeu Fabra University, ESADE Business School, Universitat Ramon Llull, Autonomous University of Barcelona, Universitat Politècnica of Valencia, University of Navarra, University of Sevilla, University of Valencia, IE University, University of Zaragoza, Autonomous University of Madrid, Universidad de Castilla La Mancha and University of Valladolid, represent $22.5 \%$ of the total number of publications with international collaborations.

It is worth noting that the collaboration level of academics from Chilean universities with other Latin American universities is low. Only the Universidade Federal do Rio of Janeiro appear in the Top 30 although some other may appear at lower positions.

Table 7 Ranking of international universities that collaborate with Chilean universities in management research

\begin{tabular}{|c|c|c|c|c|c|c|c|c|}
\hline$R$ & University & Country & $T P M$ & $T C M$ & $H M$ & $T C M / T P M$ & $\% P$ & $T P G$ \\
\hline 1 & $\begin{array}{l}\text { Massachusetts Institute } \\
\text { of Technology (MIT) }\end{array}$ & USA & 21 & 1,123 & 13 & 53.5 & $0.02 \%$ & 95,977 \\
\hline 2 & Harvard University & USA & 15 & 256 & 8 & 17.1 & $0.01 \%$ & 295,870 \\
\hline 3 & Columbia University & USA & 14 & 130 & 6 & 9.3 & $0.01 \%$ & 105,529 \\
\hline 4 & $\begin{array}{l}\text { Johns Hopkins } \\
\text { University }\end{array}$ & USA & 7 & 201 & 5 & 28.7 & $0.01 \%$ & 128,715 \\
\hline 5 & University of Georgia & USA & 7 & 140 & 5 & 20.0 & $0.01 \%$ & 46,846 \\
\hline 6 & $\begin{array}{l}\text { University of California } \\
\text { Los Angeles }\end{array}$ & USA & 7 & 94 & 5 & 13.4 & $0.01 \%$ & 132,626 \\
\hline 7 & $\begin{array}{l}\text { Tel Hai Academy } \\
\text { College }\end{array}$ & Israel & 7 & 50 & 5 & 7.1 & $1.28 \%$ & 549 \\
\hline 8 & $\begin{array}{l}\text { University of } \\
\text { Pennsylvania }\end{array}$ & USA & 6 & 112 & 4 & 18.7 & $0.01 \%$ & 118,114 \\
\hline 9 & $\begin{array}{l}\text { University of Southern } \\
\text { California }\end{array}$ & USA & 5 & 77 & 4 & 15.4 & $0.01 \%$ & 65,718 \\
\hline 10 & Yale University & USA & 6 & 58 & 4 & 9.7 & $0.01 \%$ & 92,166 \\
\hline 11 & University of Manchester & UK & 5 & 54 & 4 & 10.8 & $0.01 \%$ & 81,948 \\
\hline 12 & Universidade de Lisboa & Portugal & 4 & 22 & 4 & 5.5 & $0.01 \%$ & 44,351 \\
\hline 13 & University of London & UK & 7 & 47 & 3 & 6.7 & $0.00 \%$ & 287,060 \\
\hline 14 & $\begin{array}{l}\text { University of Minnesota } \\
\text { Twin Cities }\end{array}$ & USA & 4 & 1,293 & 3 & 323.3 & $0.00 \%$ & 111,407 \\
\hline 15 & $\begin{array}{l}\text { University of California } \\
\text { Berkeley }\end{array}$ & USA & 4 & 225 & 3 & 56.3 & $0.00 \%$ & 118,927 \\
\hline 16 & Pompeu Fabra University & Spain & 5 & 94 & 3 & 18.8 & $0.05 \%$ & 9,388 \\
\hline 17 & Georgetown University & USA & 4 & 64 & 3 & 16.0 & $0.02 \%$ & 25,765 \\
\hline 18 & ESADE Business School & Spain & 5 & 61 & 3 & 12.2 & $1.29 \%$ & 388 \\
\hline
\end{tabular}


Table 7 Ranking of international universities that collaborate with Chilean universities in management research (continued)

\begin{tabular}{|c|c|c|c|c|c|c|c|c|}
\hline$R$ & University & Country & $T P M$ & $T C M$ & $H M$ & $T C M / T P M$ & $\% P$ & $T P G$ \\
\hline 19 & Universitat Ramon Llull & Spain & 5 & 61 & 3 & 12.2 & $0.23 \%$ & 2,166 \\
\hline 20 & University of Montreal & Canada & 6 & 51 & 3 & 8.5 & $0.01 \%$ & 67,378 \\
\hline 21 & University of Ottawa & Canada & 4 & 46 & 3 & 11.5 & $0.01 \%$ & 41,150 \\
\hline 22 & New York University & USA & 4 & 44 & 3 & 11.0 & $0.01 \%$ & 66,830 \\
\hline 23 & University of Melbourne & Australia & 4 & 40 & 3 & 10.0 & $0.01 \%$ & 71,514 \\
\hline 24 & Marmara University & Turkey & 3 & 37 & 3 & 12.3 & $0.04 \%$ & 7,526 \\
\hline 25 & $\begin{array}{l}\text { Universidade Federal do } \\
\text { Rio de Janeiro }\end{array}$ & Brazil & 6 & 35 & 3 & 5.8 & $0.02 \%$ & 34,124 \\
\hline 26 & University of Liverpool & UK & 4 & 29 & 3 & 7.3 & $0.01 \%$ & 43,707 \\
\hline 27 & $\begin{array}{l}\text { Autonomous University } \\
\text { of Barcelona }\end{array}$ & Spain & 3 & 24 & 3 & 8.0 & $0.01 \%$ & 40,319 \\
\hline 28 & University of Michigan & USA & 4 & 22 & 3 & 5.5 & $0.00 \%$ & 137,102 \\
\hline 29 & $\begin{array}{l}\text { Carnegie Mellon } \\
\text { University }\end{array}$ & USA & 3 & 17 & 3 & 5.7 & $0.01 \%$ & 29,508 \\
\hline 30 & Cornell University & USA & 3 & 43 & 2 & 14.3 & $0.00 \%$ & 104,998 \\
\hline
\end{tabular}

\section{Implications and conclusions}

The results obtained in the present research coincide with other studies (Olavarrieta and Villena, 2014; Olavarrieta, 2015; Ronda-Pupo, 2016; Coronado et al., 2016), which demonstrate that research in business and management in Latin America, and particularly in Chile, has developed significantly in the last 25 years.

A significant increase is observed, particularly from 2010 onwards. This is coincidental with the increase of researchers with a doctoral degree that have been incorporated to Chilean universities, some of them benefited by the scholarships programs of Becas Chile Conicyt, as mentioned in the introduction.

It is interesting to analyse the evolution which publications in different subareas have shown. The largest growths are observed in Business, Management and Finance, while the slowest growth is Public Administration, consistent with what is happening in Latin America (Ronda-Pupo, 2016). A more detailed analysis could be performed in future work, identifying emerging areas of research such as, for example, entrepreneurship and innovation themes in the business field or venture capital in finance areas.

Moreover, the three leading business schools in Chile emerge as the most influential ones in business and management publications in the study period. Universidad de Chile is located in first place, followed by Pontificia Universidad Católica de Chile and Universidad Adolfo Ibánez. When performing an analysis by subareas, Universidad de Chile in Management and Pontificie Universidad Católica de Chile in Finance, Business and Public administration are prominent

Generating research partnerships with international universities and participating in research networks has been a strategy addressed by Chilean researchers. Thus, the results of the analysis show more than 50 universities with which joint work has been 
undertaken, mainly highlighting universities in the USA, the UK, Spain and other European universities.

Very few Latin American universities are prominent among the most influential universities with which Chilean university academics collaborate in order to publish in WoS. This leads us to reflect on the need of enhancing alliances and networks in the research field with Latin America and Asia/Pacific universities.

Scientific publications in the field of business management have undoubtedly acquired major importance in recent decades, both globally and in Latin America. In terms of Administrative science, understanding and analysing the evolution that scientific research in this area has had in Chile allows generating evidence, which is an area that is in a growth and consolidation process. However, it is necessary for this relevance and development to also be reflected in national scientific research instances, for example the National Commission for Scientific and Technological Research in Chile (Conicyt) where there is currently no study group for the business and management areas, which could boost their growth even more.

On the other hand, it is necessary to continue making an effort by having quality journals indexed in the WoS locally, which enable researchers who are at initial stages to also have options of publishing locally. The latter regarding the need and importance of having scientific/empirical results connected to Chilean and Latin American reality and issues.

The results of this work could be interesting to analyse for the rest of the universities in Latin America, and others developing countries, which are interested in joining the world trend by developing universities with a scientific focus, where Business School academics present a greater number of scientific publications available in the most important databases (WoS, Scopus, SCielo, etc.). Therefore, if the example of the Chilean universities case is followed, it could be reflected with efforts in generating policies in order to increase their academics' productivity in the areas of business and management, whether they are through: offering economic funding that promotes the development of a greater number of scientific research; delivery of prizes and bonuses based on productivity and impact of publications; or even the obligation for academics to apply on a yearly basis to competitive public grants which have scientific and technological development in each country as the ultimate goal. These efforts and good practices, which have been applied for years by other areas of knowledge developed in universities (engineering, medicine, science, etc.), should also be incorporated into the Business schools of Chilean and Latin American universities. This will allow academics in the business and management disciplines to increase the number of their scientific publications and also their influence, responding more efficiently to the development of knowledge which their economies require and their contribution to local and regional development.

\section{Acknowledgements}

We would like to thank the guest editors and the anonymous reviewers for valuable comments that have improved the quality of the paper. Valuable assistant support by Belén Paz Pacheco and Bruce Lezama are also appreciated. 


\section{References}

Aacsb (2016) Chile, Data as Accredited Member, Available from http://www.aacsb.edu/ accreditation/accredited-members/global-listing?F_Country=Chile

America Economia (2016) Ranking MBA Programs, Available from http://mba.americaeconomia. com/ranking-mba-2016/lugar/2

Blanco-Mesa, F., Merigó, J.M. and Gil-Lafuente, A.M. (2017) 'Fuzzy decision making: a bibliometric-based review', Journal of Intelligent and Fuzzy Systems, Vol. 32, pp.2033-2050.

Bonilla, C., Merigó, J.M. and Torres-Abad, C. (2015) 'Economics in latin america: a bibliometric analysis', Scientometrics, Vol. 105, pp.1239-1252.

Broadus, R.N. (1987) 'Toward a definition of 'bibliometrics', Scientometrics, Vol. 12, pp.373-379.

Cancino, C., La Paz, A.I., Ramaprasad, A. and Thant, S. (2018) 'Technological innovation for sustainable growth: an ontological perspective', Journal of Cleaner Production, Vol. 179, April, pp.31-41.

Cancino, C., Merigó, J.M. and Coronado, F. (2017a) 'Big names in innovation research: a bibliometric overview', Current Science, Vol. 113, No. 8, pp.1507-1518.

Cancino, C., Merigó, J.M. and Coronado, F. (2017b) 'A bibliometric analysis of leading universities in innovation research', Journal of Innovation and Knowledge, Vol. 2, pp.106-124.

Cancino, C., Merigó, J.M., Coronado, F., Dessouky, Y. and Dessouky, M. (2017c) 'Forty years of computers and industrial engineering: a bibliometric analysis', Computers and Industrial Engineering, Vol. 113, pp.614-629.

Conicyt (2016) Information About Graduated Students. Available from http://www.conicyt.cl/becas-conicyt/impacto/graduados/

Coronado, F., Merigó, J.M. and Cancino, C. (2016) Leading Universities in Latin America in Business and Management Research, Working paper series 2015.05. Available from http://www.cid.uchile.cl/wp/WP-2015-05.pdf

Gantman, E.R. and Fernández Rodríguez, C.J.F. (2016) 'Literature segmentation in management and organization studies: the case of Spanish-speaking countries (2000-10)', Research Evaluation, Vol. 4, No. 1, pp.461-471.

Kaushik, A., Kumar, S., Luthra, S. and Haleem, A. (2014) 'Technology transfer: enablers and barriers - a review', International Journal of Technology, Policy and Management, Vol. 14, No. 2, pp.133-159.

Kessler, M.M. (1963) 'Bibliographic coupling between scientific papers', American Documentation, Vol. 14, pp.10-25.

Koljatic, M. and Silva, M. (2001) 'The international publication productivity of Latin American countries in the economics and business fields', Scientometrics, Vol. 31, pp.381-394.

Laengle, S., Merigó, J.M., Miranda, J., Slowinski, R., Bomze, I., Borgonovo, E., Dyson, R.G., Oliveira, J.F. and Teunter, R. (2017) 'Forty years of the European journal of operational research: a bibliometric overview', European Journal of Operational Research, Vol. 262, pp.803-816.

Martínez-López, F.J., Merigó, J.M., Valenzuela, L. and Nicolás, C. (2018) 'Fifty years of the European journal of marketing: a bibliometric analysis', European Journal of Marketing, Vol. 52, pp.439-468.

Merigó, J.M., Cancino, C., Coronado, F. and Urbano, D. (2016) 'Academic research in innovation: a country analysis', Scientometrics, Vol. 108, No. 2, pp.559-593.

Merigó, J.M., Gil-Lafuente, A.M. and Yager, R.R. (2015) 'An overview of fuzzy research with bibliometric indicators', Applied Soft Computing, Vol. 27, pp.420-433.

Merigó, J.M., Pedrycz, W., Weber, R. and de la Sotta, C. (2018) 'Fifty years of information sciences: a bibliometric overview', Information Sciences, Vol. 432, pp.245-268. 
Nicholls-Nixon, C.L., Castilla, J.A.D., Sanchez-García, J. and Pesquera, M.R. (2011) 'Latin American management research: review, synthesis and extension', Journal of Management, Vol. 37, No. 4, pp.1178-1227.

Olavarrieta, S. (2015) 'Using expert judgments to rank 45 Latin American business journals', Revista De Administraçao De Empresas., Vol. 56, No. 3, pp.302-314.

Olavarrieta, S. and Villena, M. (2014) 'Innovation and business research in Latin America: an overview', Journal of Business Research, Vol. 67, No. 4, pp.489-497.

Rehman, S., Tiwari, A. and Turner, C. (2015) 'Innovation outsourcing: a review of literature', International Journal of Technology, Policy and Management, Vol. 15, No. 4, pp.333-356.

Romero-Torres, M., Acosta-Moreno, L.A. and Tejada-Gómez, M.A. (2013) 'Ranking de revistas científicas en latinoamérica mediante el índice $\mathrm{H}$ : estudio de caso Colombia', Revista Española De Documentación Científica, Vol. 36, No. 1, pp.1-13.

Ronda-Pupo, G.A. (2016) 'Knowledge map of Latin American research on management: trends and future advancement', Trends and Developments, Vol. 55, No. 1, pp.3-27.

Ruiz-Torres, A., Penkova, S. and Villafane, C. (2012) 'Evaluación y clasificación de revistas arbitradas en el area de administración de empresas publicadas en español', Academia: Revista Lationamericana De Administración, Vol. 51, No. 3, pp.48-64.

Tur-Porcar, A., Mas-Tur, A., Merigó, J.M., Roig-Tierno, N. and Watt, J. (2018) 'A bibliometric history of the Journal of Psychology between 1936 and 2015', Journal of Psychology, Vol. 152, pp.199-225.

Valenzuela, L., Merigó, J.M., Johnston, W., Nicolás, C. and Jaramillo, F. (2017) ‘Thirty years of the journal of business and industrial marketing: a bibliometric analysis', Journal of Business and Industrial Marketing, Vol. 32, pp.1-18.

Van Eck, N.J. and Waltman, L. (2010) 'Software survey: VOSviewer, a computer program for bibliometric mapping', Scientometrics, Vol. 84, pp.523-538.

World Bank (2016) Overview of the Chilean Economic Development, Available from http://www.bancomundial.org/es/country/chile/overview 